\title{
PREVALENCE AND FACTORS ASSOCIATED WITH DEPRESSION IN MEDICAL STUDENTS
}

\author{
Juliane dos Anjos de Paula ${ }^{1}$, Ada Maria Farias Sousa Borges ${ }^{2}$, Louise Rayra Alves Bezerra², \\ Helena Vieira Parente ${ }^{2}$, Rafael César dos Anjos de Paula3 ${ }^{3}$ Rubens Wajnsztejn ${ }^{4}$, \\ Alzira Alves de Siqueira Carvalho ${ }^{5}$, Vitor Engrácia Valenti5, Luiz Carlos de Abreu ${ }^{5}$
}

Clinical applications of the study: Interventions are vital in the field of Public Health to take care of the professionals who look after the population. Medical students with a high prevalence of depression have difficulty caring for people both during and after their graduation when exercising their function as doctors.

\begin{abstract}
Introduction: depression, besides causing great psychological distress, may lead to poor academic performance and social relationships. Objective: to examine the prevalence of depressive symptoms in medical students from a northeastern region of Brazil. Methods: the population comprised 1024 students from first to twelfth semesters of two medical schools in Cariri, Ceará, Brazil. We used the questionnaire on sociodemographic characteristics and the Beck Depression Inventory II version. Results: the prevalence in this population for the diagnosis of depression was $28.8 \% .652$ (63.7\%) complied with all protocols to stay in research. After logistic regression, had a negative impact on studentsmental health: female Odds Ratio adjusted (ORa) (95\% CI): 1.83 (1.19 to 2.82), reasonable physical health ORa (95\% CI): 3.15 (2 0.09 to 4, 73), uncertainty about professional future ORa (95\% CI): 2.97 (1.65 to 5.34), desire to change course ORa (95\% CI): 2.51 (1.63 to 3.86$)$, good social relationship but without participation in social activities ORa (95\% CI): 1.96 (1.27 to 3.04), relationship difficulties ORa (95\% CI): 11.40 (4.32 to 30.14$)$ and rare leisure activities (95\% CI): 2.45 ( 1.49 to 4.04 ) or eventual leisure activities ORa ( $95 \%$ CI): 3.04 (1.70 to 5.42 ). Conclusion: there was a high prevalence of depression among medical students in this region. Female, reasonable physical health, uncertainty over future career, desire to change course, do not participate in social activities and / or difficulties in relationships, sporadic or rare leisure activity were associated with increased risk of developing depressive symptoms.
\end{abstract}

Key words: depression, students, medical, prevalence, depressive disorder, education medical.

\section{INTRODUCTION}

Depression is a significant contributor to the global burden of disease and affects people in all communities across the world. Today, depression is estimated to affect 350 million people. The World Mental Health Survey conducted in 17 countries found that on average about 1 in 20 people reported having had an episode of depression in the previous year ${ }^{1}$.

The clinical symptoms of depression ${ }^{2,3}$ are; depressed mood, sadness, loss of interest, significant weight loss or gain, insomnia or hypersomnia, agitation or psychomotor retardation, fatigue or loss of energy, feelings of worthlessness or excessive or inappropriate guilt, indecisiveness or diminished ability to think or concentrate and recurrent thoughts of death. Besides causing great psychological distress, depression can lead to poor academic performance and social relationships ${ }^{4}$.

The term depression has been used in several studies to denote both depressive symptoms and depressive disorders; however the presence of symptoms may not necessarily correspond to a depressive episode.

Factors closely related to depression are drug abuse and suicide; many individuals seek drugs as

1 Psychiatrist. Master in Health Sciences. Postgraduate Program in Health Sciences. Faculty of Medicine of ABC, Santo André, SP, Brazil.

2 Faculty of Medicine, Juazeiro do Norte- Estácio/FMJ. Ceará, Brazil.

3 Doctor, Medical Residency Program in Neurology. University Hospital Edgar Santos - UFBA/BA. Salvador, Bahia, Brazil.

4 Professor of Pediatric Neurology. Department of Neuroscience. Faculty of Medicine at ABC. Santo André, SP. Brazil.

5 Laboratory for Design of Studies and Scientific Writing. Department of Collective Health Collective. Faculty of Medicine at ABC. Santo André, SP. Brazil.

Article arising from the dissertation of a postgraduate degree in Health Sciences at the Faculty of Medicine, ABC: "Prevalence of Depressive Symptoms and Associated Factors in Medical Students of Northeastern Sertão", Santo André, SP, 2014.

Corresponding author: julianepaula2@hotmail.com

Suggested citation: de Paula JA, et al. Prevalence and factors associated with depression in medical students. 24(3): 274-281 Manuscript submitted May 19 2014, accepted for publication Oct 212014. 
a way to relieve symptoms of depression or alternatively, depression can be related to the withdrawal from a substance ${ }^{5}$. Suicide is an important indicator of the severity of a depressive episode ${ }^{2}$.

Throughout life, the prevalence of depressive disorders in the general population is around 7\%, while that of depressive symptoms is around $12.6 \%{ }^{2,3}$. These symptoms can impair the functional and psychosocial lives of individuals, and, when not recognized and treated, may constitute a risk for a major depressive disorder ${ }^{4}$.

Studies performed ${ }^{6,7}$ with college students revealed rates of illness for some types of psychiatric disorder at the time of graduation of around 15$25 \%$.Depressive and anxiety disorders were the most prevalent 6,7 .

Among university students, students from medical school have been consistently targeted in research related to depression, presenting prevalence for depressive disorders ranging from $8-64 \%{ }^{5-9}$. This wide variation may be explained by the variety of existing validated instruments for surveying depressive symptoms in nonclinical populations as well as the different established cutoff points.

It has been suggested that stressful events during medical training are possible triggers of depressive symptoms such as: little leisure time, contact with disease and death, the aggressiveness inherent in many medical procedures, difficulty in communicating bad news to patients and their families and "problem patients" 10.

Depression is a public health problem and although it is prevalent among higher education professionals ${ }^{6,7}$, it affects many strata of society ${ }^{6,7}$. In view of the above, the objective of this study was to estimate the prevalence of depressive symptoms and their association with the sociodemographic and psychosocial aspects of medical students from a northeastern region of Brazil.

\section{METHODS}

This was a cross-sectional study conducted from September to November 2013, with a population consisting of 1024 medical students; 356 students from the Federal University of Cariri (UFCa) and 668 students from the Faculty of Medicine Juazeiro do Norte - Estacio/FMJ.

The students signed a "Free and Informed Consent" form (FIC) prior to participation in the study. Filling in the sociodemographic questionnaire and the Beck Depression Inventory version II were characterized as inclusion criteria.

The choice of which courses to include in the study was made due to their similar number of semesters and academic years. The undergraduate course in medicine is divided into three modules: basic ( $1^{\text {st }}$ to $4^{\text {th }}$ semester), intermediate ( $5^{\text {th }}$ to $8^{\text {th }}$ semester) and internship ( $9^{\text {th }}$ to $12^{\text {th }}$ semester).

Of the potential population (1024), 652 $(63.7 \%)$ fulfilled all the relevant criteria to remain in the study. Any students who participated in the survey as facilitators were excluded.
The sociodemographic characterization questionnaire was applied, containing 24 questions, in addition to the following supplementary data: course duration, university, age, sex, skin color, state and country of birth, marital status, offspring, religion, place of residence, transportation used to get to college, remunerated activities, physical health, alcohol and tobacco use, lifestyle, social relationships, satisfaction with the course, among others; together with the Beck Depression Inventory version II (BDI-II).

The BDI-II is a standardized, selfadministered questionnaire configured as a selfassessed measurement of the symptoms of depression. It consists of 21 statements which vary in intensity from zero to three, thus having a final score ranging from zero to 63.

The established cut-off points followed the criteria of the most recent BDI-II validated in Brazil in community samples, with zero to ten points corresponding to normal and from 11-points onwards constituting depression ${ }^{11,12}$.

Depression was adopted as the dependent variable, analyzed according to the independent variables sex, institution of higher learning, the course module, age, religion, marital status, perceived physical health, tobacco use, alcohol use, leisure activities, quality of social relationships, uncertainty regarding future career and desire to change courses.

From the completed questionnaires a database was designed in the STATA program, version 12 , in which were developed descriptive and inferential statistics, using tables with absolute and relative frequencies, mean, standard deviation, maximum, minimum, prevalence coefficient and the Pearson's chi-squared test, adopting a statistical significance value of $\mathrm{pd}^{\prime \prime} 0.05$.

After the Chi-Squared test, from the variables which presented a p-value of up to 0.2 with the variable depression, a multinomial logistic model was developed, obtaining Odds Ratio (OR) values as a function of the variables retained in this model, allowing the interpretation the OR estimates and confidence interval (CI) already adjusted for variables involved in this analysis ${ }^{13,14}$.

The project was approved by the Ethics Committee of the Faculty of Medicine of ABC, Opinion number: 268.234.

\section{RESULTS}

Tables 1 to 4 present the descriptive and associative events of depression.

The study included 652 students (63.7\%) distributed in all semesters of medical school at two institutions located in the region of Cariri, one private $(68.9 \%)$ and the other public $(31.1 \%)$. The majority of the participants were; enrolled in the basic module $(44.3 \%)$, female $(58.9 \%)$, with a mean age of $22.74 \pm 3.68$ and the highest concentration in the range of 20 to 27 years old $(73.0 \%)$, the skin color was predominantly white (58.9\%) (Table 1). 
Most students came from the state of Ceará $(75.6 \%)$, while $93.5 \%$ were unmarried, $50.3 \%$ were in a loving relationship and $71.2 \%$ were Catholic. More than half lived with their family (55.1\%) and $29.5 \%$ lived with other students (Table 1 ). Regarding social relationships, $60.7 \%$ reported relating well with friends and relatives and frequently participated in social activities. $40.5 \%$ of the students occasionally took part in leisure activities and $66.3 \%$ chose medical school willingly.

Generally, the main form of transport for the students was their own car $(46.6 \%)$. The majority of students did not carry out any remunerated activities (82.5\%), but it was observed that students from the public Higher Education Institution (HEI), although mostly not engaging in any paid activity $(65.3 \%)$ did carry out more educational activities with a grant $(30.2 \%)$ when compared with the private school students $(3.3 \%)$, this fact probably reflects the distinct opportunities in the HEI. Most students described their physical health as good, consumed alcohol but did not use tobacco.
The prevalence found in this population for the diagnosis of depression was $28.8 \%$, and the average score of the depressed students in the BDIII was $16.9 \pm 6.4$ (Table 2 ), $10.34 \%$ of the students had suicidal thoughts (Table 3 ).

Following the Pearson's chi-squared test, the variables $(p<0.20)$ selected for the logistic regression model were: $\operatorname{sex}(p<0.001)$, religion $(p=0.185)$, physical health $(p<0.001)$, smoking $(p=0.111)$, uncertainty about professional future $(p<0.001)$, desire to change courses $(p<0.001)$, social relationships $(p<0.001)$ and leisure activities $(p<0.001)$. Since marital status $(p=0.342)$ was a factor commonly associated with depressive symptoms the decision was made to include this variable in the logistic regression (Table 4).

The following variables were not entered in the logistic regression model: institution of higher education ( $p=0.441)$, course module $(p=0.439)$, age $(p=0.950)$ and alcohol use $(p=0.472)$.

In the adjusted model, the selected variables were able to explain $23.54 \%$ of the diagnosis of depression in the study participants $\left(r^{2}=0.2354\right)$.

Table 1: Distribution of the 652 medical students by socio-demographic characteristics, from the region of Crajubar/Cariri Ceará, Northeast Brazil, in 2014

\begin{tabular}{|c|c|c|c|}
\hline Demographic variables & Categories & $\mathbf{N}$ & $\%$ \\
\hline \multirow[t]{3}{*}{ Course module } & Basic & 289 & 44.3 \\
\hline & Intermediate & 255 & 39.1 \\
\hline & Internship & 108 & 16.6 \\
\hline \multirow[t]{2}{*}{ Type of institution } & Private & 448 & 68.9 \\
\hline & Public & 202 & 31.1 \\
\hline \multirow[t]{3}{*}{ Age } & Up to 19 years & 112 & 17.6 \\
\hline & 20 to 27 years & 464 & 73.0 \\
\hline & 28 years or over & 60 & 9.4 \\
\hline \multirow[t]{2}{*}{ Sex } & Masculine & 268 & 41.1 \\
\hline & Feminine & 384 & 58.9 \\
\hline \multirow[t]{4}{*}{ Skin color } & White & 386 & 59.7 \\
\hline & Black & 16 & 2.5 \\
\hline & Mixed & 231 & 35.7 \\
\hline & Yellow & 14 & 2.2 \\
\hline \multirow[t]{4}{*}{ Region of origin } & Not identified & 7 & 1.1 \\
\hline & CE & 493 & 75.6 \\
\hline & NE & 110 & 16.9 \\
\hline & Outside the NE & 42 & 6.4 \\
\hline \multirow[t]{3}{*}{ Marital Status } & Single with partner or boy/girlfriend & 326 & 50.3 \\
\hline & Single with no partner or boy/girlfriend & 280 & 43.2 \\
\hline & Married/Stable relationship & 42 & 6.5 \\
\hline \multirow[t]{4}{*}{ Religion } & Catholic & 460 & 71.2 \\
\hline & Spiritualist & 30 & 4.6 \\
\hline & Other & 72 & 11.1 \\
\hline & No religion & 84 & 13.0 \\
\hline \multirow[t]{5}{*}{ Living arrangements } & Live with relatives & 359 & 55.1 \\
\hline & Live alone & 79 & 12.1 \\
\hline & Live with other students & 192 & 29.5 \\
\hline & Live in guesthouse & 9 & 1.4 \\
\hline & Live in the student's house & 12 & 1.8 \\
\hline
\end{tabular}

$* \mathrm{~N}=$ number of sample; $\%=$ percentage. 
Table 2: Distribution of the 652 medical students classified as the absence or presence of depression according to the Beck Depression Inventory version II, from the region of Crajubar/Cariri Ceará, Northeast Brazil, in 2014

$\begin{array}{llllc}\text { Depression classification } & \text { N } & \text { PC } & \text { Mean } \pm \text { SD* } & \text { Min-Max* } \\ \text { Without depression } & 464 & 71.2 & 4.6 \pm 2.9 & 0-10 \\ \text { Depression } & 188 & 28.8 & 16.9 \pm 6.4 & 11-54\end{array}$

* Scores obtained in the Beck Depression Inventory; SD = Standard deviation; Min-Max = Minimum value-Maximum value.

$\mathrm{N}=$ number of sample; $\mathrm{PC}=$ Prevalence coefficient.

Table 3: Distribution of the 652 medical students according to the question about suicidal thoughts (question 9) showing the average scores and minimum and maximum values obtained in the Beck Depression Inventory version II, from the region of Crajubar/Cariri Ceará, Northeast Brazil, in 2014

$\begin{array}{llccc}\text { Variables } & \text { Categories } & \text { N } & \text { Mean } \pm \text { SD* } \\ \text { Suicidal thoughts } & \text { I have no ideas about killing myself } & 583 & 6.94 \pm 5.32 & 0-32 \\ & \text { I have ideas but I would not execute them } & 59 & 19.19 \pm 8.20 & 4-35 \\ & \text { I would like to kill myself } & 3 & 22.33 \pm 11.93 & 14-36 \\ & \text { I would kill myself if I hadthe opportunity } & 1 & 54.00 & -\end{array}$

* Scores obtained in the Beck Depression Inventory; SD = Standard deviation; Min-Max = Minimum value Maximum value.

$\mathrm{N}=$ number of sample; $\mathrm{PC}=$ Prevalence coefficient.

Table 4: Results from the univariate and multiple logistic regression model, from the region of Crajubar/Cariri Ceará, Northeast Brazil, in 2014

\begin{tabular}{|c|c|c|c|c|c|}
\hline Variables & Categories & $\mathbf{N}(\%)$ & $X^{2}(p) *$ & $\mathrm{OR}\left(\mathrm{IC}_{95 \%}\right) * *$ & $\mathrm{ORa}\left(\mathrm{CI}_{95 \%}\right) * * *$ \\
\hline Sex & $\begin{array}{l}\text { Masculine } \\
\text { Feminine }\end{array}$ & $\begin{array}{c}55(20.5) \\
133(34.6)\end{array}$ & $15.321(<0.001)$ & $\begin{array}{c}1.00 \\
2.05(1.43-2.91)\end{array}$ & $\begin{array}{c}1.00 \\
1.83(1.19-2.82)\end{array}$ \\
\hline Religion & $\begin{array}{l}\text { Catholic } \\
\text { Spiritualist } \\
\text { Other } \\
\text { No religion }\end{array}$ & $\begin{array}{l}122(26.5) \\
13(43.3) \\
22(30.6) \\
27(32.1)\end{array}$ & $4.821(0.185)$ & $\begin{array}{c}1.00 \\
2.12(1.00-4.49) \\
1.22(0.71-2.10) \\
1.31(0.79-2.17)\end{array}$ & $\begin{array}{l}N S \\
N S \\
N S \\
N S\end{array}$ \\
\hline Marital Status & $\begin{array}{l}\text { Single with partner or } \\
\text { boy/girlfriend } \\
\text { Single with no partner } \\
\text { or boy/girlfriend } \\
\text { Married/stable relationship }\end{array}$ & $\begin{array}{l}86(26.4) \\
89(31.8) \\
12(28.6)\end{array}$ & $2.145(0.342)$ & $\begin{array}{c}1,00 \\
1.3(0.91-1.85) \\
1.12(0.55-2.28)\end{array}$ & $\begin{array}{l}\text { NS } \\
\text { NS } \\
\text { NS }\end{array}$ \\
\hline Health & $\begin{array}{c}\text { Poor } \\
\text { Reasonable } \\
\text { Good/Excellent }\end{array}$ & $\begin{array}{c}3(37.5) \\
113(44.7) \\
72(18.4)\end{array}$ & $51.876(<0.001)$ & $\begin{array}{c}2.66(0.62-11.38) \\
3.58(2.50-5.11) \\
1.00\end{array}$ & $\begin{array}{c}N S \\
3.15(2.09-4.73) \\
1.00\end{array}$ \\
\hline Use tobacco & $\begin{array}{l}\text { Not use tobacco } \\
\text { Use tobacco }\end{array}$ & $\begin{array}{l}177(28.2) \\
10(43.5)\end{array}$ & $2.535(0.111)$ & $\begin{array}{c}1.00 \\
1.96(0.84-4.55)\end{array}$ & $\begin{array}{l}N S \\
N S\end{array}$ \\
\hline $\begin{array}{l}\text { Uncertainty } \\
\text { about the future }\end{array}$ & $\begin{array}{c}\text { Not have } \\
\text { Little/medium } \\
\text { A lot }\end{array}$ & $\begin{array}{c}21(16.9) \\
121(26.9) \\
46(59.7)\end{array}$ & $45.091(<0.001)$ & $\begin{array}{c}1.00 \\
1.81(1.08-3.02) \\
7.28(3.78-13.99)\end{array}$ & $\begin{array}{c}1.00 \\
N S \\
2.97(1.65-5.34)\end{array}$ \\
\hline $\begin{array}{l}\text { Desire to change } \\
\text { courses }\end{array}$ & $\begin{array}{l}\text { No } \\
\text { Yes }\end{array}$ & $\begin{array}{l}101(21.6) \\
86(47.5)\end{array}$ & $42.793(<0.001)$ & $\begin{array}{c}1.00 \\
3.29(2.28-4.74)\end{array}$ & $\begin{array}{c}1.00 \\
2.51(1.63-3.86)\end{array}$ \\
\hline \multirow[t]{2}{*}{ Social Relationships } & $\begin{array}{l}\text { Relates well and } \\
\text { participates } \\
\text { in social activities } \\
\text { Relates well but } \\
\text { does not participate } \\
\text { in social activities }\end{array}$ & $71(18.1)$ & $75.382(<0.001)$ & $2.99(2.06-4.34)$ & $1.96(1.27-3.04)$ \\
\hline & Difficulties in relationships & $26(78.8)$ & & $16.19(7.01-40.21)$ & $11.40(4.32-30.14)$ \\
\hline Leisure Activities & $\begin{array}{c}\text { Always } \\
\text { Sporadically } \\
\text { Rarely }\end{array}$ & $\begin{array}{l}35(14.2) \\
85(32.4) \\
66(74.5)\end{array}$ & $50.883(<0.001)$ & $\begin{array}{c}1.00 \\
2.89(1.86-4.50) \\
5.45(3.34-8.88)\end{array}$ & $\begin{array}{c}1.00 \\
2.45(1.49-4.04) \\
3.04(1.70-5.42)\end{array}$ \\
\hline
\end{tabular}

* Pearson's chi-squared test $\left(\chi^{2}\right)$, variables which presented $p<0.20$ were included in the univariate and multiple logistic regression model.

** $\quad \mathrm{OR}=$ Odds Ratio, $* * * \mathrm{ORa}=$ adjusted Odds Ratio.

CI $95 \%=$ confidence interval; $N=$ number of sample; NS = Not significant. 


\section{DISCUSSION}

The prevalence of depressive symptoms and associated factors in medical students in a northeastern region of Brazil was highlighted as a serious public health problem ${ }^{1,4}$.

The prevalence of depressive symptoms found was $28.8 \%$, and the mean BDI-II score was $16.9 \pm 6.4$ (Table 2); the prevalence of depressive disorders in the general population is around $7 \%$ and depressive symptoms throughout life, around $12.6 \%{ }^{2,3}$.

These symptoms may also lead to disturbance in the functional and psychosocial lives of the individuals, and may pose a risk for major depressive disorders when not recognized and treated ${ }^{4}$.

It was observed that the higher the intensity of suicidal thoughts reported in question 9 of the BDI-II, the greater the average overall score found. Of the $10.34 \%$ of students who had some suicidal thoughts at the time of evaluation, the majority had scores for depression (BDI> 10) (Table 3).

Studies ${ }^{8,9,15-20}$ using the BDI with cut-off points similar to those used in this study, found that the prevalence of depressive symptoms ranged from $13.9 \%$ to $48.2 \%$. This broad variation seems to be indicative of bias in the data collection, which hinders comparisons between studies, only allowing them to be treated as similar.

A higher prevalence of depressive symptoms has been reported in students in the basic modu$\mathrm{le}^{21}$. One study ${ }^{9}$ found that almost half $(48.2 \%)$ the students had depressive symptoms, and of these, $20.7 \%$ had mild symptoms, $16.6 \%$ moderate symptoms, and $10.9 \%$ severe symptoms. The prevalence of these symptoms was higher among first $(64 \%)$ and second year (62\%) students, and lowest in fourth year students $(33 \%)^{9}$.

In this study, it was found that the prevalence of depressive symptoms decreased as the course progressed, going from $31.1 \%$ in the basic module, to $27.8 \%$ in the intermediate module and $25 \%$ during the internship. The higher incidence of depression during the basic module could be related to changes in the routine of students entering medical school who receive a large amount of information, increased workload related to their studies and an abrupt change in the method of study 22 .

On the other hand, the findings of MeloCarrilho et al $^{23}$ verified a significant increase in depressive symptoms in medical students attending the eighth semester (fourth year); this fact was associated with the beginning of the internship. In agreement, Costa et $\mathrm{al}^{15}$ estimated the prevalence of depressive symptoms in students during the medicine internship to be around $40.5 \%$. Factors such as contact with disease and death, the aggression inherent in many interventions, difficulties in communicating bad news, in addition to the need for specialization at the end of the course may be responsible for this symptomatology ${ }^{8}$.

In the instrument used, the BDI-II, suicide is the most serious negative outcome of a depressive disorder. Studies ${ }^{20,24}$ have related suicidal thoughts among medical students to; stressful events, severe depressive and anxiety symptoms, loss of control, personality disorder, and lack of stable relationships.

In the first analysis, using the chi-squared test, an association was found between depressive symptoms and the following variables: gender, physical health, uncertainty regarding professional future, desire to change courses, social relationships and leisure activities (Table 4).

After logistic regression, we found that women had a 1.83 times higher chance of developing depression compared to men (Table 4). Studies have shown that the female sex is a significant risk factor for depression both in university populations and in the general population. 9,25-27.

The presence and severity of depressive symptoms have been linked to the early university years and the female sex ${ }^{9}$. Jadoon et al ${ }^{25}$ verified that females had 2.01 more chances for depression than their male peers. Over the years the gap between activities considered male and female has narrowed, leaving responsibilities almost equivalent, but it has been observed that students of different sexes have a distinct response pattern to stress ${ }^{22}$.

Generally speaking, women in our society, besides accumulating academic and professional activities, have multiple roles such as motherhood, home and social responsibilities, as well as an increased predisposition to mood changes resulting from hormonal influences, which could partly explain the higher predisposition to depressive disorders in this population ${ }^{28}$.

In the adjusted model, religion, marital status and tobacco use showed no statistical significance in this study (Table 4). In a study by Jadoon et al. 25 , age, marital status, location, and household income were not determining factors in the prevalence of depression in medical students. However, in relation to smoking, some studies have shown higher chances for depression in tobacco users. Among the medical students smokers were 2.2 times more likely to have depressive symptoms than non-smokers ${ }^{29}$.

Another study ${ }^{30}$ on this issue verified that students who smoked regularly had significantly higher levels of depression. Our results demonstrated an odds ratio of 1.96 CI95\% (0.84 to 4.55 ) for depressive symptoms in smokers, which was not statistically significant.

Vasegh \& Mohammadi ${ }^{31}$ suggested that religious belief could be a possible protective factor for depressive and anxiety symptoms, but no statistical significance was found for depression.

The perception of physical health as reasonable compared to a perception of good health presented 3.15 times more chances of leading to depression (Table 4). Studies focusing on quality of life detected a significant deterioration in the vitality, physical and mental health domains in a prospective study on the quality of life related to the health of medical students 32,33 .

Among the students who had a lot of uncertainty about their professional future; the chance of depression was 2.97 higher than in those 
who had no uncertainty about their future (Table 4). In related studies 32,33 it was suggested that an exhaustive workload, lack of time for physical activities and a decrease in leisure activities on a daily basis may be related to poor physical and mental performance.

The uncertainty about their professional future as well as the desire to change courses presented increasing occurrence as the student had doubts about what they aimed for in the future (Table 4). Studies ${ }^{34,35}$ evaluating the correlation between the degree of satisfaction of medical students with their course and the score obtained in the Beck Depression Inventory (BDI), verified that the greater the involvement and satisfaction of the student in their course, the lower the presence of symptoms of depression, with lower scores in the BDI.

The chances of depression in those who related well but did not participate in social activities were 1.96 times higher compared to those who were well-connected (Table 4). Those who claimed to have relationship difficulties presented 11.40 times more chances of depression compared to those who related well and participated in social activities. Those who sporadically and rarely participated in leisure activities were more vulnerable to suffer from depressive symptoms, the odds being 2.45 times and 3.04 times respectively for the development of the disease (Table 4).

Costa et al ${ }^{15}$ assessed students during internship and found that the variables with the greatest impact associated with the onset of depressive symptoms were: thoughts of leaving the course, emotional stress and regular academic performance.

The adjusted model was able to explain $23.54 \%$ of the diagnosis of depression in the study participants; a relatively high value considering depression is a multifactorial disease (Table 4). In addition to environmental causes, other factors such as temperament, for example neuroticism; genetics, for example individuals with first-degree relatives who have major depressive disorders have a 2-4 times higher risk of developing the disease than the general population; physiological factors such as endocrine disease and course modifications are involved in the development of symptoms ${ }^{2}$.

Finally it was found that the prevalence of depression in medical students was higher than in the general population ${ }^{2}$. In comparative studies it was found that the prevalence ranged from $13.9 \%$ to $48.2 \%$. However, these studies $8,9,15-20$ were performed using previous versions of the BDI. The results expressed in tables 1 -4 report similar prevalences although with a version of the instrument which is more current and more reliable regarding the composition and analysis of the results.

The suicidal thoughts referred to by question 9 in the BDI-II were directly proportional to the severity of depression according to the score obtained in this instrument.

On the other hand, even when diagnosed, the medical students did not seek professional help ${ }^{36,37}$. Protocols ${ }^{23}$ have been suggested for the implementation of psychoeducation programs with the aim of enhancing adhesion of the individual to a treatment routine. Rethinking the role of the institution and the medical curriculum in causing, maintaining and preventing the detected symptoms could alleviate this problem ${ }^{15,20}$.

In the region of Cariri, in the cities of Juazeiro do Norte - Ceará, Brazil and Barbalha, Ceará, Brazil, in the two medical schools studied there is a shortage of mental health services focused on psychiatric and psychological support to medical students.

Of the $100 \%$ of students who could have composed the sample, $63.7 \%$ actually participated in the research. This response rate is similar to other studies on universities $25,20,36,38$.

From the point of view of limitations of the study, it appears that depressed patients may present significant somatic complaints and individuals with clinical disease often present more depressive symptoms. The uncertainty regarding their professional future, desire to change courses, relationship difficulties and level of participation in social and leisure activities could also be interpreted as resulting from the depressed state due to symptoms such as pessimism, low self-esteem, impaired decision-making capacity and feelings of isolation which may have corresponded to the moment of depression.

Another limitation concerning the use of the BDI-II, which aims to detect depressive symptoms and not the presence or absence of a depressive episode, is that it is not possible either to establish a temporal relationship between the onset of symptoms and entering university as the BDI- II only evaluates the presence of symptoms in the previous two weeks, or to establish causality between the associations found. These findings on the prevalence of depressive symptoms in medical students are expected to impact on conduct in the field of public health, seeing that imminent actions may be directed to take care of the professionals who look after people.

As emphasized by Atrash and Karpentier ${ }^{39}$, health is often defined as a result of complex interactions, being something which is in constant motion and depends on regular attention and active maintenance. In particular, achieving good quality public health depends not only on the ability to make the right choices relating to the environment which determines the current state of health of a population, but also to make the right choices and take appropriate action to avoid foreseeable threats. On the other hand, translational medicine processes should be seen as essential for better handling the serious problems faced by the Public Health, such as depression, as it involves possible processes to improve the quality of life of the people involved.

In conclusion, it was found that in the region of Cariri, located in northeastern Brazil, the overall prevalence of depressive symptoms in medical students was $28.8 \%$. The female sex, reasonable physical health, uncertainty over future career, desire to change courses, not participating in social activities and/or difficulties in relationships and 
sporadic or rare leisure activity were associated with a higher risk of developing depressive symptoms. Such associations can also be considered as arising from depressive symptoms resulting in a negative perception of the facts and social isolation.

\section{REFERENCES}

1. Organização Mundial da Saúde. Mental Health Home. Disponível em: http://www.who.int/ mental_health/management/depression/en/ Acesso em 17/11/2012.

2. American Psychiatric Association. Diagnostic and statistical manualof mental disorders: DSM-5. Washington: American Psychiatric Publishing; 2013.

3. CID-10. Classificação Internacional das doenças e problemas relacionados à saúde. São Paulo: EDUSP; 1997.

4. Rodrigues RS, Santos SC, Cataldo Neto A et al. Depressão em alunos de medicina. Acta Médica 2006; 27:374-380.

5. Chiapetti N, Serbena CA. Uso de álcool, tabaco e drogas por estudantes da área de saúde de uma Universidade de Curitiba. Psicologia: Reflexão e Crítica 2007;20(2):303-136.

6. Cerchiari EAN, Caetano D, Faccenda O. Prevalência de transtornos menores em estudantes universitários. Estudos em Psicologia 2005; 10(3): $413-420$.

7. Cavestro JM, Rocha FL. Prevalência de depressão entre estudantes universitários. J. Bras. Psiquiatr2006; 55 (4): 264-67.

8. Baldassin S, Alves TC, de Andrade AG, Nogueira Martins LA.The characteristics of depressive symptoms in medical students during medical education and training: a cross-sectional study. BMC Med Educ 2008 Dec 11;8:60. doi: 10.1186/1472-6920-8-60.

9. Al-Faris EA, Irfan F, Van der Vleuten CP, Naeem $\mathrm{N}$, Alsalem A, Alamiri N, Alraiyes T, Alfowzan M, Alabdulsalam A, Ababtain A et al: The prevalence and correlates of depressive symptoms from an Arabian setting: a wakeup call. Medical teacher 2012; 34 (1):S32-36.

10. Silva LCG, Rodrigues MMP. Eventos estressantes na relação com o paciente e estratégias de enfrentamento: estudo com acadêmicos de medicina. J Bras Psiquiatr 2004;53(3): 185-96.

11. Wang YP, Gorenstein C. Psychometric properties of the Beck Depression Inventory-II: a comprehensive review. Rev Bras Psiquiatr 2013; 35(4): 416-431

12. Gomes-Oliveira MH, Gorenstein C, Neto FL, Andrade LH, Wang YP. Validation of the Brazilian Portuguese version of the Beck Depression Inventory-II in a community sample. RevBrasPsiquiatr 2012;34(4):389-394.

13. Kleinbaum DG, Kupper LL, Nizam A, Muller KE. Applied regression analysis and other multivariable methods. Chapter two.Australia: Brooks/Cole; 2008.

14. Hamilton, LC. Statistics with Stata : updated for version 12. Eighth edition. Cengage; 2012;
Rethinking the role of the institution and the medical curriculum in the causing, maintenance and prevention of the detected symptoms could be one solution to minimize the impact on the mental health of medical students.

15. Costa EF, Santana YS, Santos AT, Martins LA, Melo EV, Andrade TM. Depressive symptoms among medical intern students in a Brazilian public university. Rev Assoc Med Bras 2012 JanFeb;58(1):53-9.

16. Sherina MS, Rampal L, KanesonN.Psychological stress among undergraduate medical students. Med J Malaysia 2004 Jun;59(2):207-11.

17. Ahmed I, Banu H, Al-Fageer R, Al-SuwaidiR. Cognitive emotions: depression and anxiety in medical students and staff. J CritCare 2009 Sep;24(3):e1-7. doi: 10.1016/j. jcrc. 2009. 06.003.

18. Givens JL, Tjia J. Depressed medical students' use of mental health services and barriers to use. AcadMed 2002 Sep;77(9):918-21.

19. Sun L, Sun LN, Sun YH, Yang LS, Wu HY, Zhang DD, Cao HY, Sun Y.Correlations between psychological symptoms and social relationships among medical undergraduates in Anhui Province of China. Int J PsychiatryMed 2011;42(1):29-47.

20. Curran TA, Gawley E, Casey P, Gill M, Crumlish N. Depression, suicidality and alcohol abuse among medical and business students. Ir Med J 2009 Sep;102(8):249-52.

21. Aktekin M1, Karaman T, Senol YY, Erdem S, Erengin $\mathrm{H}$, Akaydin M. Anxiety, depression and stressful life events among medical students: a prospective study in Antalya, Turkey. MedEduc 2001 Jan;35(1):12-7.

22. Colares MFA. As Fontes de tensapo no curso meidico: um estudo psicomeitrico. Ribeirapo Preto. Dissertação [Mestrado] - Universidade de SãoPaulo;1999.

23. Melo-Carrillo A, Van Oudenhove L, Lopez-Avila A. Depressive symptoms among Mexican medical students: high prevalence and the effect of a group psychoeducation intervention. J AffectDisord 2012 Feb;136(3):1098-103. doi: 10.1016/j.jad.2011.10.040.

24. Tyssen R, Vaglum P, Grønvold NT, EkebergO.Suicidal ideation among medical students and young physicians: a nationwide and prospective study of prevalence and predictors. J Affect Disord 2001 Apr; 64(1): 69-79.

25. Jadoon NA, Yaqoob R, Raza A, Shehzad MA, Zeshan SC. Anxiety and depression among medical students: a cross-sectional study. J Pak Med Assoc 2010 Aug; 60(8): 699-702.

26. Roh MS, Jeon HJ, Kim H, Han SK, HahmBJ.The prevalence and impact of depression among medical students: a nationwide cross-sectional study in South Korea. AcadMed 2010 Aug;85(8):1384-90. doi: 10.1097/ACM. 0b013 e 3181 df5 e 43.

27. AlviT,Assad F, RamzanM,Khan FA. Depression, anxiety and their associated factors among 
medical students.JColl Physicians SurgPak 2010 Feb; 20(2):122-6.

28. Brandtner M, Bardagi M. Sintomatologia de Depressão e Ansiedade em Estudantes de uma Universidade Privada do Rio Grande do Sul. Gerais: Revista Interinstitucional de Psicologia, Gerais: Revista Interinstitucional de Psicologia 2009 jul-dez; 2 (2): 81-91.

29. Güleç M, Bakir B, Ozer M, Uçar M, Kiliç S, Hasde $M$. Association between cigarette smoking and depressive symptoms among military medical students in Turkey. Psychiatry Res $2005 \mathrm{Apr}$ 30;134(3):281-6.

30. Aniebue PN, OnyemaGO.Prevalence of depressive symptoms among Nigerian medical undergraduates. TropDoct $2008 \mathrm{Jul} ; 38(3)$ :1578. doi: 10.1258/td.2007.070202.

31. Vasegh S, MohammadiMR.Religiosity, anxiety, and depression among a sample of Iranian medical students. Int J PsychiatryMed 2007;37(2):213-27.

32. Alves JGB, Tenorio M, Anjos AG, Figueroa JN. Qualidade de vida em estudantes de Medicina no início e final do curso: avaliação pelo Whoqol-bref. Rev. bras. educ. med 2010 Mar. 34(1): 91-96. http://dx.doi.org/10.1590/ S0100-55022010000100011.

33. Meyer C, Guimaraes ACA, Machado Z, Parcias SR. Qualidade de vida e estresse ocupacional em estudantes de medicina. Rev. bras. educ. med 2012 Dec; 36(4): 489-498.

34. Rezende CHA, Abrapo CB, Coelho EP, Passos LBS. Prevalencia de Sintomas Depressivos en- tre Estudantes de Me- dicina da Universidade Federal de Uberlandia. RevBrasEducMed $2008 ; 32(3): 315-23$.

35. Swami V1, Chamorro-Premuzic T, Sinniah D, Maniam T, Kannan K, Stanistreet D, FurnhamA.General health mediates the relationship between loneliness, life satisfaction and depression. A study with Malaysian medical students. Soc Psychiatry PsychiatrEpidemiol 2007 Feb;42(2):161-6.

36. Schwenk TL, Davis L, Wimsatt LA. Depression, stigma, and suicidal ideation in medical students. JAMA 2010 Sep 15;304(11):118190. doi: 10.1001/jama.2010.1300.

37. Chang E, Eddins-Folensbee F, Porter B, Coverdale J.Utilization of counseling services at one medical school. South Med J 2013 Aug;106(8):449-53. doi: 10.1097/ SMJ.0b013e3182a05994.

38. Chang E, Eddins-Folensbee F, Coverdale J. Survey of the prevalence of burnout, stress, depression, and the use of supports by medical students at one school. AcadPsychiatry 2012 May ;36(3):177-82. doi: 10.1176/ appi.ap. 11040079 .

39. Atrash HK, Carpentier R. The evolving role of public health in the delivery of health care. Journal of Human Growth and Development. 2012; 22(3): 396-399.

40. Figueiredo JL, Vinegoni C, de Abreu LC. Perinatal health and translational medicine. Journal of Human Growth and Development. 2013; 23(2): 125-127.

\section{RESUMO}

Introdução: a depressão, além de causar grande sofrimento psíquico, pode levar a prejuízos no desempenho acadêmico e nos relacionamentos sociais. Objetivo:estimar a prevalência de sintomas depressivos e sua associação com aspectos sociodemográficos e psicossociais em estudantes de medicina de uma região do Sertão Nordestino, Brasil. Método: apopulação foi constituída por 1024 estudantes do primeiro ao décimo segundo períodos do curso de medicina de duas escolas médicas do Cariri, Sertão Nordestino, Ceará, Brasil. Utilizou-se o questionário de caracterização sociodemográfica e o Inventário de Depressão de Beck versão II. Resultados: a prevalência encontrada nessa população para o diagnóstico de depressão foi de $28,8 \% .652(63,7 \%)$ cumpriram com todos os protocolos para permanência na pesquisa. Apresentaram impacto negativo na saúde mental dos estudantes no modelo ajustado de regressão logística: sexo feminino OddsRatio ajustado (ORa) $\left(\mathrm{IC}_{95 \%}\right): 1,83(1,19-2,82)$, saúde física razoável ORa $\left(\mathrm{IC}_{95 \%}\right): 3,15(2,09-4,73)$,incerteza quanto ao futuro profissional ORa (IC $95 \%$ : $2,97(1,65-5,34)$, desejo de mudar de curso ORa $\left(\mathrm{IC}_{95 \%}\right): 2,51(1,63-3,86)$, relacionamento social bom porém sem participação de atividades sociais ORa $\left(\mathrm{IC}_{95 \%}\right): 1,96(1,27-3,04)$, dificuldades de relacionamento ORa $\left(\mathrm{IC}_{95 \%}\right): 11,40(4,32-30,14)$ e raras atividades de lazer ORa $\left(\right.$ IC $\left._{95 \%}\right): 2,45(1,49-4,04)$ ou esporádicas atividades de lazer ORa $\left(\right.$ IC $_{95 \%}$ ): $3,04(1,70-5,42)$. Conclusão: observou-se alta prevalência de depressão nos estudantes de medicina nesta região. Sexo feminino, saúde física razoável, incerteza quanto ao futuro profissional, desejo de mudar de curso, não participação de atividades sociais e/ou dificuldades de relacionamentos, esporádica ou rara atividade de lazer foram associados a maior chance de desenvolver sintomas depressivos.

Palavras-chave: depressão, estudantes de medicina, prevalência, transtorno depressivo, educação médica. 